\title{
Reconnaissance Geologic Map of Kodiak Island and Adjacent Islands, Alaska
}

Compiled by Frederic H. Wilson

Pamphlet to accompany

Scientific Investigations Map 2999 



\section{Contents}

Introduction and Previous Work ............................................................................................... 1

Geologic and Physiographic Framework ……………........................................................ 1

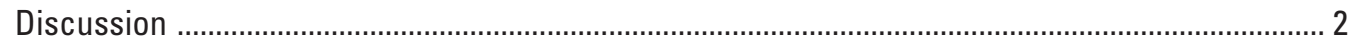

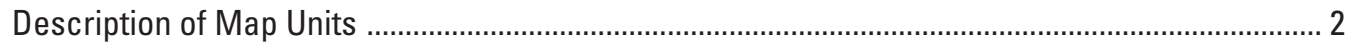

Surficial Deposits and Sedimentary Rocks ...................................................................... 2

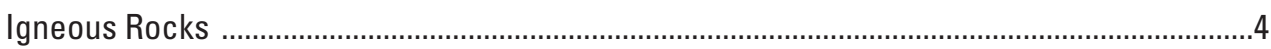

Metamorphic and Tectonic Rocks ..................................................................................... 4

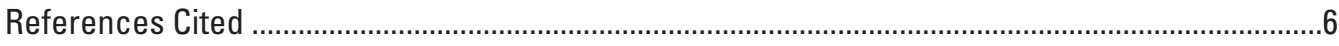

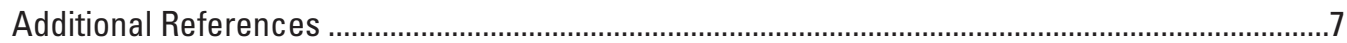





\section{Introduction and Previous Work}

This map and its associated digital files (Wilson and others, 2005) represent part of a systematic effort to release geologic map data for the United States in a uniform manner. The geologic data in this series have been compiled from a wide variety of sources, ranging from state and regional geologic maps to large-scale field mapping. The map data are presented herein for use at a nominal scale of 1:500,000, although individual datasets (see Wilson and others, 2005) may contain data suitable for use at larger scales; the metadata associated with each dataset provides more detailed information on sources and appropriate scales for use. Associated attribute databases accompany the spatial database of the geology and are uniformly structured for ease in developing regional- and national-scale maps.

Kodiak Island and its adjacent islands, located on the west side of the Gulf of Alaska, contain one of the largest areas of exposure of the flysch and melange of the Chugach terrane of southern Alaska. However, in the past 25 years, only detailed mapping covering small areas in the archipelago has been done. The map and associated digital files present the best available mapping compiled in an integrated fashion. The primary source for the map of Kodiak Island and islands to the south is the reconnaissance mapping of George W. Moore (Moore, 1967), augmented by his unit descriptions (Moore, 1969), as well as new mapping on the west coast by William Connelly and J. Casey Moore (Connelly, 1978; Connelly and Moore, 1979) and on the east coast by Moore and others (1983). George Moore's map (Moore, 1967), in turn, is based heavily on mapping by Capps (1937), which also is the major source for the map of Afognak Island. However, a recent (2001-04) unpublished vegetation survey of Afognak Island by Page Spencer (National Park Service) and Michael Fleming (USGS) indicates that part of Afognak Island mapped by Capps (1937) as the Kodiak Formation consists of granitic rocks that are probably similar to rocks of the Kodiak batholith on Kodiak Island; thus, areas shown as granitic rocks on the map of Afognak Island have been inferred from photographs taken as part of this vegetation survey, in conjunction with available aeromagnetic data (Saltus and Simmons, 1997). A brief field visit to an area of magnetic rocks in the mountains east of Kazakof Bay showed the rocks at that location to be a highly indurated, possibly hornfelsed, clean sandstone, atypical of the graywacke of the Kodiak Formation. Mapping of the surficial deposits on Afognak Island has been derived from Landsat-image and topographic-map interpretation. The geology of Sitkinak Island has been derived from Clendenen and others (1992). Important interpretations of some of the geologic units as discussed in Plafker and others (1994) have been incorporated here where appropriate.

\section{Geologic and Physiographic Framework}

The accretionary flysch and melange of the late Mesozoic Chugach terrane (Plafker and others, 1977) is an important part of Kodiak Island and its adjacent islands. Also present in the map area are accreted components of the Prince William terrane (the Ghost Rocks and Sitkalidak Formations), which are present in the southeastern part of the map area, as well as Tertiaryoverlap rock units (Plafker and others, 1994). The flysch of the Chugach terrane, which here is represented by the Kodiak Formation, is intruded by Paleocene granitic rocks that typically are referred to as the Kodiak batholith. These Paleocene plutons were emplaced in a near-trench setting, possibly owing to the subduction of a spreading center (Marshak and Karig, 1977; Moore and others, 1983; Bradley and others, 2000). The Ghost Rocks Formation is the melange and trench-deposited flysch of the Prince William terrane; the Sitkalidak Formation is an outer-fan turbidite, thought to be related to the same depositional system (Plafker and others, 1994). Volcanic and mafic hypabyssal rocks within the Ghost Rocks Formation possibly are comagmatic with the granitic rocks of the Kodiak batholith (Hill and others, 1981); both tholeiitic basalt and calc-alkaline andesite are present. Because of this relation, Plafker and others (1994) suggested that the Ghost Rocks Formation, although younger than the Kodiak Formation, predates intrusion of the Kodiak batholith and, therefore, is of latest Cretaceous and early Paleocene age. Granitic plutonic rocks intruding the Ghost Rocks Formation commonly are assumed (for example, Plafker and others, 1994) to be an extension of the Kodiak batholith; however, on this map they are shown as a distinct geologic unit because they are more altered and contain little biotite. If they truly are distinct from the Kodiak batholith, then the age of the Ghost Rocks Formation remains poorly constrained. The Sitkalidak Formation is also poorly age constrained; however, evidence suggests an Eocene and Oligocene age (Moore, 1969; Plafker and others, 1994). Tertiary overlap sequences indicate an initial terrestrial phase followed soon after by marine deposition at water depths of 100 to $186 \mathrm{~m}$ (Clendenen and others, 1992). This was succeeded in turn by deposition of the shallow-water Narrow Cape Formation, which is of limited areal extent. Clendenen and others (1992) described a new unit as the informally named Albatross sedimentary sequence, which was originally mapped by Moore (1967) as part of the Sitkinak Formation on Sitkinak Island; they interpreted it to be equivalent to the Yakataga Formation in northern Southeast Alaska and suggested that it was deposited in conditions transitional between glaciomarine and fluvial conditions. The youngest sedimentary rock unit of the Kodiak Island area, the late Pliocene and early Pleistocene Tugidak Formation (Moore, 1969), is richly fossiliferous; its sedimentary characteristics suggest deposition in continuing glaciomarine conditions (Armentrout, 1979); part of this unit also has been correlated with the Yakataga Formation (Moore, 1969).

Physiographically, Kodiak Island and its adjacent islands show strong effects from Pleistocene and Holocene glaciation. Well-developed fjords and, locally, glacial deposits provide abundant evidence for the glaciers and ice cap that covered much of the islands (Karlstrom and Ball, 1969). Mann and Peteet (1994) provided dates and stratigraphic sections, which indicate that glaciers from Shelikof Strait flowed on land, as much as $10 \mathrm{~km}$ inland, at the same time that an ice cap covered much of the island. Nonetheless, very little mapping of Quaternary geology in the Kodiak Island area has been reported in the literature. 


\section{Discussion}

Ultimately, much better mapping is needed in the Kodiak Island area to resolve the age relations and distribution of geologic units. Unpublished anecdotal reports, such as those of Page Spencer and Michael Fleming (oral commun., 2004) mentioned above, suggest that additional outcrops of the Kodiak batholith may be found on densely forested Afognak Island. Plutons intruding the Ghost Rocks Formation need dating, as do the volcanic rocks within the unit. Studies of the Quaternary history and glaciation are minimal (see, for example, Mann and Peteet, 1994). The geologic units of the Kodiak Island area figure prominently in many tectonic reconstructions in the literature (see, for example, Marshak and Karig, 1977; Moore and others, 1983; Clendenen and others, 1992; Bradley and others, 2000), yet mapping of these units is, at best, only at reconnaissance scale.

\section{DESCRIPTION OF MAP UNITS}

\section{SURFICIAL DEPOSITS AND SEDIMENTARY ROCKS}

Qs Surficial deposits, undivided (Quaternary) - Unconsolidated, poorly to well sorted, poorly to moderately well stratified deposits. Consists predominantly of alluvial, colluvial, glacial, marine, lacustrine, eolian, and swamp deposits

QTtg Tugidak Formation (early Pleistocene and late Pliocene) - Consists of 1,500 m of interbedded sandstone and siltstone that contains randomly distributed pebbles and cobbles of glacialmarine origin (Allison, 1978). Single 1-m-thick cobble-conglomerate bed is reported $350 \mathrm{~m}$ above base of unit (Allison, 1978). Unit is richly fossiliferous, containing marine fossils of Pliocene age. Allison (1978, p. 177) reported occurrence of diverse fauna, which consists of more than 80 species that are "largely composed of living, cold-water, North Pacific and Arctic taxa" and indicate cold-water conditions, colder than present-day Gulf of Alaska. On the basis of available fauna, Allison (1978) suggested that deposition took place in upper part of outer-neritic zone, at water depths between 91 and $145 \mathrm{~m}$

Ty Albatross sedimentary sequence of Clendenen and others (1992) (Pliocene or late Miocene)-Diamictite, sandstone, and siltstone. Also includes conglomerate horizons that contain clasts of granite, chert, melange, and slate. Conglomerate also contains distinctive calcareous-shale clasts that are unlike any nearby exposed units in that they contain late early Miocene fauna of foraminifers and flora of diatoms; however, unit in which clasts are enclosed is correlated with part of the Yakataga Formation of Yakutat area, $500 \mathrm{~km}$ to east

Tnc Narrow Cape Formation (middle Miocene) - Unit is $700 \mathrm{~m}$ thick: lower two thirds consists of sandstone and a few conglomerate beds; upper one third is siltstone. Basal sedimentary breccia and conglomerate contains clasts derived from the underlying Sitkalidak Formation; fossiliferous (Nilsen and Moore, 1979). Overlying breccia is highly bioturbated, massive, silty, fine-grained sandstone and siltstone that makes up more than 90 percent of formation (Nilsen and Moore, 1979). At irregular intervals, contains thin (as much as $70 \mathrm{~cm}$ thick) conglomeratic layers consisting of well-rounded granitic and volcanic pebbles, clasts of the underlying Sitkalidak Formation, and disarticulated, broken, and partly rounded megafossil fragments (Nilsen and Moore, 1979). Rich marine fauna is present in the Narrow Cape Formation; Allison (1978) indicated that formation contains at least 80 taxa that include Acila, Clinocardium, Cyclocardia, Mya, Colus, Cryptonatica, Anadara, Chione, Dosinia, and gastropod Ficus. Range and variety of invertebrate fossils provide strong indication of warm-water conditions within temperate-climate belt of Hall (1964)

Tsti Siltstone of Trinity Islands of Clendenen and others (1992) (earliest Miocene or late Oligocene)-Siltstone deposited in cool-temperature climactic conditions at outer-neritic water depths. Originally included in the Narrow Cape Formation, unit is now considered to be distinctive, older unit. Unit is highly bioturbated siltstone and very-fine-grained sandstone, containing sporadic conglomeratic layers (Nilsen and Moore, 1979). Nilsen and Moore (1979) reported that fossils are abundant but are of low species diversity. Allison and Marincovich (1981; see also, Allison, 1978) indicated that this unit "was deposited in the outer neritic zone of the continental shelf." Their best interpretation of depth ranges of taxa found in unit suggested deposition in water depths of 100 to $200 \mathrm{~m}$. Fauna also suggest cool-temperate marine climate, significantly cooler than that represented by the (younger) Narrow Cape Formation, to which this unit was originally assigned 
Tsk Sitkinak Formation (Oligocene) - Conglomerate and cross-bedded sandstone and siltstone that contains coal fragments. Unit is $1,500 \mathrm{~m}$ thick in its type section along south shore of Sitkinak Island. According to Nilsen and Moore (1979), outcrops of the Sitkinak Formation on Sitkalidak and Sitkinak Islands consist of two different facies. On Sitkalidak Island, lower part of unit is conglomerate that contains rounded clasts of volcanic rocks, graywacke, chert, and carbonate rocks; upper section is turbidite sandstone and interbedded shale. Overall sequence represents an inner-fan or lower-slope environment that has channel or canyon fill (Nilsen and Moore, 1979). On Sitkinak Island, "formation consists of alternating conglomerate-sandstone units and fine-grained sandstone and siltstone units with some coal and carbonaceous shale strata" (Nilsen and Moore, 1979, p. 19-20); conglomerate contains well-rounded clasts of volcanic rocks, vein quartz, argillite, graywacke, red chert, and granite. Section probably represents conglomerate-sandstone channels enclosing interchannel, lagoonal, and interdistributary-bay deposits (Nilsen and Moore, 1979). Very few marine fossils are known from unit, whereas abundant plant fragments and fossil leaves have been collected from siltstone-coal strata (Nilsen and Moore, 1979)

Tsi Sitkalidak Formation (Oligocene and Eocene)-Uniform sandstone and siltstone in graded beds; few conglomerate beds. Total thickness about 3,000 m. Fossil crab, Callianassa aff. C. porterensis, indicates Oligocene age (Moore, 1969); Moore (1969) assigned Eocene and Oligocene age on the basis of this fossil and evidence from superposition. Clendenen and others (1992) reported Eocene foraminifers but only reported Eocene age for unit. Because of reported presence of Oligocene-age fossil crab in unit, unit age is herein revised to conform to Moore's (1969) original age assignment (Eocene and Oligocene)

Kcct Cape Current terrane of Connelly (1978) (Late Cretaceous) - Informal unit described by Connelly (1978) as consisting principally of medium- to thick-bedded arkosic and lithic sandstone that contains sparse sections of vesicular pillow lava and pillow breccia. Slightly metamorphosed and moderately deformed. Two bodies of red pelagic limestone containing many silicieous layers are present within unit along southern shore of Shuyak Island. Limestones, which are thin bedded and tightly folded, contain sparse coccoliths of indeterminate age and Late Cretaceous foraminifera (approximately Turonian to early Santonian age, according to W.V. Sliter, written commun., in Connelly, 1978)

Kkd Kodiak Formation (Late Cretaceous) - Consists of medium- to thick-bedded, graded-bed sequences, which average $1 \mathrm{~m}$ thick, of arkosic wacke and shale and occasional beds of pebbly conglomerate. Flute casts and complete Bouma sequences indicate deposition by turbidity currents below wave base. Strikes to northeast and dips steeply to northwest; is generally deformed in tight, large-scale folds. Moore (1969) designated type section as rocks exposed along western shore of Uyak Bay. Base of section is $4 \mathrm{~km}$ south of head of bay, where lower part of formation is intruded by pluton; top of section is $3 \mathrm{~km}$ south of village of Uyak, where rocks of the Uyak Complex (Kmk) are thrust over the Kodiak Formation. As a result, neither a true lower or upper contact is known for the Kodiak Formation. Subsequent work by Nilsen and Moore (1979) indicated that unit is approximately 5,000 m thick, in contrast to estimated thickness of 30,000 $\mathrm{m}$ as originally suggested by Moore (1969). Nilsen and Moore (1979) found that unit is repeated structurally by folding and faulting, which makes internal stratigraphic correlation difficult. Nilsen and Moore (1979) used a "turbidite facies and facies-association" scheme that generally follows system of Mutti and Ricci Lucchi (1972, 1975, as cited in Nilsen and Moore, 1979) and Nelson and Nilsen (1974, as cited in Nilsen and Moore, 1979); under this system, the Kodiak Formation consists largely of basin-plain- and slope-facies associations. Basin-plain facies is structurally lowest part of the Kodiak Formation and is characteristic of most of formation on southeast side of Kodiak Island (Nilsen and Moore, 1979). It "consists of repetitively interstratified graded sandstone beds and hemipelagic shales, typically $30 \mathrm{~cm}$ thick. $* * *$ Sandstone:shale ratios range in general from 1:1 to 1:5. The interstratified hemipelagic shale is generally bioturbated; trace fossils typically are those of the surface-grazing deep-marine Nereites facies and include Helminthoida and Helminthopsis as well as larger trace fossils possibly formed by moving gastropods" (Nilsen and Moore, 1979, p. 6). Slope-facies rocks are found primarily on northwest side of Kodiak Island and are primarily thick mudstone sequences. These "may form imbricate slices juxtaposed during multiple phases of synsedimentary slumping [and they] contain chaotically oriented blocks, slabs, and disordered fragments of hemipelagic mudstone 
that probably slid from upper slope depositional sites to the lower slope or base of slope under the influence of gravity. $* * *$ Sandstone:shale ratios are typically very low, ranging from 1:30 to 1:10" (Nilsen and Moore, 1979, p. 6). Conglomerate and sandstone channels are found locally within slope-facies associations; Nilsen and Moore (1979) mentioned their presence in Uyak Bay in particular, where they are about $50 \mathrm{~m}$ thick. Fossils from the Kodiak Formation include Inoceramus kusiroensis of Late Cretaceous (Maestrichtian) age. Correlated with the Shumagin Formation to southwest and the Valdez Group to northeast

Shuyak Formation (Late Triassic) - Consists of two members: a sedimentary member in fault contact with a volcanic member. Sedimentary member is inferred to overlie volcanic member (Connelly and Moore, 1979). Unit structurally overlies the schist of Kodiak Island (Jsch) and the Uyak Complex (Kmk) but usually is separated from them by the Afognak pluton ( $\mathrm{kqd})$. Divided into the following:

kss Sedimentary member-Volcaniclastic sequence consisting of thin- to medium-bedded lithic sandstone that contains lesser amounts of conglomerate, argillite, and siliceous tuff and is intruded by mafic dikes and sills (Connelly and Moore, 1979). As described by Connelly and Moore (1979), unit is rich in primary andesitic material and displays flute casts and complete Bouma sequences that indicate deposition by turbidity currents. Rocks either are broadly folded or dip homoclinally to southeast and have undergone prehnite-pumpellyitefacies metamorphism (Connelly and Moore, 1979)

Ksv Volcanic member-Vesicular pillow greenstone; locally contains beds of pillow-breccia agglomerate, tuff, and argillite (Connelly and Moore, 1979). Greenstone is tholeiitic in composition

\section{IGNEOUS ROCKS}

Tegr Younger granitic rocks (Eocene?) - Small, altered granitic plutons that intrude the Ghost Rocks Formation (TKgh) between Portage and Kaiugnak Bays, as well as north of Ugak Bay on southeast coast of Kodiak Island. Examination of a few thin sections of these rocks show them to be distinctive from rocks of Kodiak batholith (mapped as Tg) in that they are more altered and contain little biotite (W.L. Coonrad and F.H. Wilson, unpub. data, 1976). Although shown on Moore's (1967) map as part of his granodiorite unit, they are here separated because of their distinctive character

$\mathrm{Tg} \quad$ Granitic rocks (Paleocene) - Unit generally consists of fine-grained biotite quartz monzonite of Kodiak batholith; ranges in composition from two-mica granite to granodiorite. Intrudes flysch deposits of the Kodiak Formation (Kkd) and, in vicinity of Japanese Bay, rocks of the Ghost Rocks Formation (TKgh). K-Ar ages range from 57.1 to $62.6 \mathrm{Ma}$, majority of which cluster around $60 \mathrm{Ma}$ (Marvin and Dobson, 1979; Moore and others, 1983; Shew and Wilson, 1981); falling within this range are ${ }^{40} \mathrm{Ar} /{ }^{39} \mathrm{Ar}$ ages of $57.8 \pm 2.5$ and $58.3 \pm 0.2 \mathrm{Ma}$ reported by Bradley and others (2000). On Afognak Island, presence of rocks of Kodiak batholith is inferred from weak aeromagnetic anomalies (Saltus and Simmons, 1997), as well as from anecdotal reports that note the presence of granitic rocks (see discussion in text). All contacts on Afognak Island are hypothetical

kqd Afognak pluton (Triassic) - Large, multiphase pluton of hornblende diorite, quartz diorite, and tonalite exposed along northwestern side of Kodiak Island and neighboring islands to north (Connelly and Moore, 1979; Roeske and others, 1989). Pluton has well-developed contactmetamorphic aureole in the Shuyak Formation; boundary with the Schist of Kodiak Island (Jsch) is apparently a fault (Roeske and others, 1989). K-Ar ages on hornblende range between $188 \pm 11$ and $197 \pm 11 \mathrm{Ma}$ (Roeske and others, 1989); a U-Pb age determination of $217 \pm 10 \mathrm{Ma}$ is interpreted to indicate emplacement age (Roeske and others, 1989)

kvm Mafic dikes, sills, and plugs (Triassic?) —Diabasic bodies intruding the Shuyak Formation but having no visible thermal aureoles (Connelly and Moore, 1979)

\section{METAMORPHIC AND TECTONIC ROCKS}

TKgh Ghost Rocks Formation, undivided (Paleocene and Late Cretaceous?) - Consists of zeolitebearing tuffaceous sandstone and basalt, as well as hard claystone, sandstone, and tuff, in graded beds (wildflysch of Moore, 1969). Formation is sheared, faulted, and folded; 
estimated thickness is 5,000 meters (Nilsen and Moore, 1979). Other than intrusive contacts, all contacts with other units are faults. "The formation is lithologically distinct, as it is a coherent belt of rocks that contains pillow basalt and tuff, which are not found in either the underlying or the overlying formations" (Moore, 1969, p. A31). Although no fossils were found, Moore (1969) suggested that the Ghost Rocks Formation straddles Paleocene-Eocene boundary, on the basis of "analysis of the thickness of similar lithologies in the successive formations and a hypothetical correlation of the volcanic rocks in the Ghost Rocks Formation with nearby intrusive rocks of known age." Poorly preserved fossils reported by Plafker and others (1994) suggest latest Cretaceous and Paleocene age for limestone blocks associated with pillow basalt within this unit. Locally subdivided into the following:

TKghc Coherent sedimentary rocks-Unit B of Byrne (1981). Rocks are exposed in vicinity of Japanese Bay. Consists of "medium-bedded (10-40 cm thick beds) sandstone interbedded with similar thicknesses of shale. The sandstones and shales are rhythmically bedded and sole markings and graded beds indicate turbidite deposition" (Byrne, 1981, p. 42). Byrne (1981) interpreted these rocks as "slope basin sequences" and indicated that they were distinctive in the Ghost Rocks Formation because of their lack of contact metamorphism and because they contain only rare thick-bedded (more than $1 \mathrm{~m}$ thick) sandstone. In addition, Byrne (1981) noted absence of conglomerate and pebbly mudstone, as well as lack of igneous rocks and relative lack of deformation, as compared with other rocks in the Ghost Rocks Formation. Rocks may be inferred to be lithologically similar to basin-plain-facies association of Nilsen and Moore (1979), as described for the Kodiak Formation (unit Kkd; see description above)

TKghs Sandstone-rich unit-Massive sandstone beds, lesser amounts of argillite, and medium- to thin-bedded sandstone. Sandstone beds show Bouma sequences indicative of deposition by turbidity currents. Locally, channelized conglomerate units as much as $100 \mathrm{~m}$ thick are found on Aliulik Peninsula; clasts in conglomerate are as large as $30 \mathrm{~cm}$ and consist of chert, sandstone, limestone, and greenstone. Andesite also is interbedded on Aliulik Peninsula. Age of unit is Paleocene(?)

TKgha Argillite-rich unit-Thick sections of argillite, local massive sandstone, and chert-rich pebble conglomerate. Locally contains tuff beds. Limestone containing planktonic foraminifers is present locally at depositional contacts with pillow basalt. Unit typically is found to southeast of sandstone-rich unit (TKghs). Three collections of planktonic foraminifers yielded Late Cretaceous and early Tertiary ages. Age of unit is Paleocene(?)

TKgvb Basaltic volcanic and hypabyssal rocks-Tholeiitic basalt within both the sandstone- and argillite-rich subunits (TKghs and TKgha, respectively) of the Ghost Rocks Formation. Rocks typically are altered by shearing and low-grade metamorphism, yet "these lavas cannot have been derived from a single source and in many respects exhibit chemical affinities to magmas found in a variety of tectonic environments" (Moore and others, 1983, p. 270). Age of unit is Cretaceous(?) or Tertiary

Kmk Uyak Complex (Early Cretaceous) - Includes, in "lithologically chaotic assemblage of deep-sea rock types" (Connelly and Moore, 1979), argillite and gray chert containing minor tuff; massive arkosic sandstone; pillowed and massive greenstone; bedded radiolarian chert; minor limestone; and tuffaceous argillite. According to Connelly and Moore (1979), "most of the Uyak Complex is tectonic melange with foliation dipping steeply northwest" and "contains fossils ranging in age from Paleozoic to Early Cretaceous." The Uyak Complex is a classic melange, containing large tectonic blocks of varying lithology in matrix of gray chert and argillite. "Gabbroic and ultramafic rocks occur as kilometre-sized slabs in the northernmost exposures of the Uyak [and] are always fault bounded, and serpentinization is pronounced near their margins" (Connelly, 1978, p. 758). Sparse tectonic blocks of rhythmically bedded radiolarian chert are widely scattered throughout the Uyak Complex. Intensely deformed gray chert and argillite, which forms about 45 percent of the Uyak, is matrix to other rock types of the Uyak. Limestone blocks are uncommon in the Uyak; Connelly (1978) reported that only three localities have bodies of mappable size. Two of three limestone bodies are contorted sequences of nonfossiliferous, thin-bedded white limestone containing thin layers of argillite; third body consists of "thick-bedded, variably recrystallized grainstone with occasional layers of tuff and tuffaceous lime" (Connelly, 1978, p. 760). Variously sized tectonic blocks, none of which have remaining primary sedimentary structures, of massive wacke and contorted thinly interbedded wacke and argillite constitute about 20 percent of 
the Uyak. Petrographically similar, massive and thinly interbedded wackes are "typically medium grained, poorly sorted, and have diffuse grain boundaries surrounded by finegrained matrices of phyllosilicates (mostly chlorite), prehnite, and/or pumpyellite" (Connelly, 1978, p. 760). In the Uyak Complex, mesoscopic shear fractures and innumerable faults of unknown offset have disrupted stratigraphic continuity and juxtaposed contrasting sedimentary and igneous rocks. Slickensides are common both as subparallel, anastomosing fractures in competent rocks and as closely spaced fractures in less competent rocks. Connelly (1978) reported detailed structural analysis indicating that mean slip direction during deformation was to N. $38^{\circ} \mathrm{W} .\left( \pm 11^{\circ}\right)$ and that transport was southeast under northwest (present day), on the basis of work by Moore and Wheeler (1975). Locally subdivided into the following:

Kmu Gabbroic and ultramafic rocks - Includes layered gabbro, clinopyroxenite, dunite, and plagioclase peridotite. Found in northwesternmost exposures of the Uyak Complex as kilometer-sized slabs that are always fault bounded (Connelly, 1978); margins of slabs show pronounced serpentinization

Jsch Schist of Kodiak Island (Jurassic) - Thinly layered and complexly folded quartz-mica schist, greenschist, crossite-epidote schist (blueschist), and epidote amphibolite (Connelly and Moore, 1979). Roeske and others (1989), who called unit the "Raspberry Schist," subdivided it into two subunits: first consists of metabasite and metasedimentary rocks that have some relict textures and phases preserved, including pillow shapes and bedding; second unit. is completely recrystallized, and no original textures or phases are preserved. Carden and others (1977) reported Jurassic K-Ar metamorphic ages of 164.7 \pm 19.4 and 173.0 $\pm 5.1 \mathrm{Ma}$ on crossite and 192.2 \pm 5.6 and 196.7 $\pm 5.8 \mathrm{Ma}$ on white mica; Roeske and others (1989) reported $\mathrm{U}-\mathrm{Pb}$ isochron age of $204 \pm 8 \mathrm{Ma}$ and $\mathrm{Rb}-\mathrm{Sr}$ isochron age of $195 \pm 10 \mathrm{Ma}$ age for unit

\section{References Cited}

Allison, R.C., 1978, Late Oligocene through Pleistocene molluscan faunas in the Gulf of Alaska region: The Veliger, v. 21, no. 2, p. 171-188.

Allison, R.C., and Marincovich, Louie, Jr., 1981, A Late Oligocene or earliest Miocene molluscan fauna from Sitkinak Island, Alaska: U.S. Geological Survey Professional Paper 1233, 11 p., 3 plates.

Armentrout, J.M., 1979, Cenozoic stratigraphy, Kodiak Island Archipelago, Alaska [abs.]: Geological Society of America Abstracts with Programs, v. 11, p. 66.

Bradley, D.C., Parrish, Randall, Clendenen, William, Lux, Daniel, Layer, P.W., Heizler, Matthew, and Donley, D.T., 2000, New geochronological evidence for the timing of early Tertiary ridge subduction in southern Alaska, in Kelley, K.D., and Gough, L.P., Geologic studies in Alaska by the U.S. Geological Survey, 1998: U.S. Geological Survey Professional Paper 1615, p. 5-21.

Byrne, Timothy, 1981, Tectonic and structural evolution of the Ghost Rocks Formation, Kodiak Islands, Alaska: Santa Cruz, University of California, Ph.D. dissertation, $174 \mathrm{p}$.

Capps, S.R., 1937, Kodiak and adjacent islands, Alaska: U.S. Geological Survey Bulletin 880-C, p. 111-184.

Carden, J.R., Connelly, William, Forbes, R.B., and Turner, D.L., 1977, Blueschists of the Kodiak Islands, Alaska: An extension of the Seldovia schist terrane: Geology, v. 5, no. 9, p. 529-533.
Clendenen, W.S., Sliter, W.V., and Byrne, Tim, 1992, Tectonic implications of the Albatross sedimentary sequence, Sitkinak Island, Alaska, in Bradley, D.C., and Ford, A.B., eds., Geologic studies in Alaska by the U.S. Geological Survey, 1990: U.S. Geological Survey Bulletin 1999, p. 52-70.

Connelly, William, 1978, Uyak Complex, Kodiak Islands, Alaska: A Cretaceous subduction complex: Geological Society of America Bulletin, v. 89, no. 5, p. 755-769.

Connelly, William, and Moore, J.C., 1979, Geologic map of the northwest side of the Kodiak and adjacent islands, Alaska: U.S. Geological Survey Miscellaneous Field Studies Map MF-1057, 2 sheets, scale 1:250,000.

Hall, C.A., Jr., 1964, Shallow-water marine climates and molluscan provinces: Ecology, v. 45, no. 2, p. 226-234.

Hill, Malcolm, Morris, Julie, and Whelan, Joseph, 1981, Hybrid granodiorites intruding the accretionary prism, Kodiak, Shumagin, and Sanak Islands, southwest Alaska: Journal of Geophysical Research, p. 10,569-10,590.

Karlstrom, T.N.V., and Ball, G.E., eds., The Kodiak Island refugium, its geology, flora, fauna, and history: Toronto, Ontario, Ryerson Press, p. 7-17.

Mann, D.H., and Peteet, D.M., 1994, Extent and timing of the last glacial maximum in southwestern Alaska: Quaternary Research, v. 42, p. 136-148.

Marshak, R.S., and Karig, D.E., 1977, Triple junctions as a cause for anomalously near-trench igneous activity between trench and volcanic arc: Geology, v. 5, p. 233-236. 
Marvin, R.F., and Dobson, S.W., 1979, Radiometric ages: Compilation B, U.S. Geological Survey: Isochron/West, no. 26, p. 3-6.

Moore, G.W., 1967, Preliminary geologic map of Kodiak Island and vicinity, Alaska: U.S. Geological Survey Open-File Report 67-161, 1 sheet, scale 1:250,000.

Moore, G.W., 1969, New formations on Kodiak and adjacent islands, Alaska, in Cohee, G.V., Bates, R.G., and Wright, W.B., Changes in stratigraphic nomenclature by the U.S. Geological Survey, 1967: U.S. Geological Survey Bulletin 1274-A, p. A27-A35.

Moore, J.C., and Wheeler, R.L., 1975, Orientation of slip during early Mesozoic subduction, Kodiak Islands, Alaska [abs.]: Geological Society of America Abstracts with Programs, v. 7, p. 1,203-1,204.

Moore, J.C., Byrne, Tim, Plumley, P.W., Reid, Mary, Gibbons, Helen, and Coe, R.S., 1983, Paleogene evolution of the Kodiak Islands, Alaska: Consequences of ridge-trench interaction in a more southerly latitude: Tectonics, v. 2, no. 3, p. 265-293.

Mutti, Emiliano, and Ricci Lucchi, Franco, 1972, Le torbiditi dell'Appennino settentrionale - introduzione all'analisi di facies: Memoirs Soc. Geol. Italiana, v. 11, p. 161-199.

Mutti, Emiliano, and Ricci Lucchi, Franco, 1975, Turbidite facies and facies associations, in Mutti, E., and six others, eds., Examples of turbidite facies and facies associations from selected formations of the northern Apenines: International Geological Congress Sedimentology, 9th, Nice, France, 1975, Field Trip Guidebook A11, p. 21-36.

Nelson, C.H., and Nilsen, T.H., 1974, Depositional trends of modern and ancient deep-sea fans: Society of Economic Paleontologists and Mineralogists Special Publication 19, p. 69-91.

Nilsen, T.H., and Moore, G.W., 1979, Reconnaissance study of Upper Cretaceous to Miocene stratigraphic units and sedimentary facies, Kodiak and adjacent islands, Alaska, with a section on sedimentary petrology, by G.R. Winkler: U.S. Geological Survey Professional Paper 1093, 34 p.

Plafker, George, Jones, D.L., and Pessagno, E.A., Jr., 1977, A Cretaceous accretionary flysch and melange terrane along the Gulf of Alaska margin, in Blean, K.M., ed., The United States Geological Survey in Alaska: Accomplishments during 1976: U.S. Geological Survey Circular 751-B, p. B41-B43.

Plafker, George, Moore, J.C., and Winkler, G.R., 1994, Geology of the southern Alaska margin, in Plafker, George, Jones, D.L., and Berg, H.C., eds., Geology of Alaska: Geological Society of America, The Geology of North America, v. G-1, p. 389-449.

Roeske, S.M., Mattinson, J.M., and Armstrong, R.L., 1989, Isotopic ages of glaucophane schists on the Kodiak Islands, southern Alaska, and their implications for the Mesozoic tectonic history of the Border Ranges fault system: Geological Society of America Bulletin, v. 101, p. $1,021-1,037$.

Saltus, R.W., and Simmons, G.C., 1997, Composite and merged aeromagnetic data for Alaska: A website for distribution of gridded data and plot files: U.S. Geological Survey Open-File Report 97-520 [http://pubs.usgs.gov/of/1997/ ofr-97-0520/alaskamag.html].

Shew, Nora, and Wilson, F.H., 1981, Map and table showing radiometric ages of rocks in southwestern Alaska: U.S. Geological Survey Open-File Report 81-886, 26 p., 1 sheet, scale 1:1,000,000.

Wilson, F.H., Labay, K.A., Mohadjer, Solmaz, and Shew, Nora, 2005, Preliminary integrated geologic map databases for the United States: Digital data for the reconnaissance geologic map of the Kodiak Islands, Alaska (geologic map compiled by F.H. Wilson): U.S. Geological Survey Open-File Report 2005-1340 [http://pubs.usgs.gov/ of/2005/1340/].

\section{Additional References}

Allaway, W.H., Jr., Detterman, R.L., Miller, J.W., and Magoon, L.B., 1984, Stratigraphic clarification of the Shelikof Formation, Alaska Peninsula: U.S. Geological Survey Bulletin 1537-A, 27 p.

Detterman, R.L., and Hartsock, J.K., 1966, Geology of the Iniskin-Tuxedni region Alaska: U.S. Geological Survey Professional Paper 512, 78 p., 6 plates.

Detterman, R.L., Case, J.E., Wilson, F.H., and Yount, M.E., 1987, Geologic map of the Ugashik, Bristol Bay, and western part of Karluk quadrangle, Alaska: U.S. Geological Survey Miscellaneous Investigations Series Map I-1685, scale 1:250,000.

Detterman, R.L., Wilson, F.H., Yount, M.E., and Miller, T.P., 1987, Quaternary geologic map of the Ugashik, Bristol Bay, and western part of Karluk quadrangles, Alaska: U.S. Geological Survey Miscellaneous Investigations Series Map I-1801, scale 1:250,000.

Detterman, R.L., Miller, J.W., Case, J.E., Wilson, F.H., and Yount, M.E., 1996, Stratigraphic framework of the Alaska Peninsula: U.S. Geological Survey Bulletin 1969-A, 74 p.

Hanson, B.M., 1957, Middle Permian limestone on Pacific side of Alaska Peninsula: American Association of Petroleum Geologists Bulletin, v. 41, no. 10, p. 2,376-2,378.

Hill, M.D., 1979, Volcanic and plutonic rocks of the KodiakShumagin shelf, Alaska: Subduction deposits and neartrench magmatism: Santa Cruz, University of California, Ph.D. dissertation, $259 \mathrm{p}$.

Imlay, R.W., 1984, Early and middle Bajocian (Middle Jurassic) ammonites from southern Alaska: U.S. Geological Survey Professional Paper 1322, 38 p.

Martin, G.C., and Katz, F.J., 1912, A geologic reconnaissance of the Iliamna region, Alaska: U.S. Geological Survey Bulletin 485, $138 \mathrm{p}$.

Riehle, J.R., and Detterman, R.L., 1993, Quaternary geologic map of the Mount Katmai quadrangle and adjacent parts of the Naknek and Afognak quadrangles, Alaska: U.S. Geological Survey Miscellaneous Investigations Series Map I-2032, scale 1:250,000. 
Riehle, J.R., Detterman, R.L., Yount, M.E., and Miller, J.W., 1993, Geologic map of the Mount Katmai quadrangle and adjacent parts of the Naknek and Afognak quadrangles, Alaska: U.S. Geological Survey Miscellaneous Investigations Series Map I-2204, scale 1:250,000.

Spurr, J.E., 1900, A reconnaissance in southwestern Alaska in 1898: U.S. Geological Survey 20th Annual Report, pt. 7, p. 31-264.

Wilson, F.H., and Shew, Nora, 1992, Map and tables showing geochronology and whole-rock geochemistry of selected samples, Ugashik and part of Karluk quadrangles, Alaska: U.S. Geological Survey Miscellaneous Field Studies Map MF-1539-E, scale 1:250,000.
Wilson, F.H., Detterman, R.L., and DuBois, G.D., in press, Geologic framework of the Alaska Peninsula: U.S. Geological Survey Bulletin 1969-B, scale 1:500,000.

Wilson, F.H., Detterman, R.L., and DuBois, Gregory, 1999, Digital data for the geologic framework of the Alaska Peninsula, southwest Alaska, and the Alaska Peninsula terrane: U.S. Geological Survey Open-File Report 99-317 [http:// geopubs.wr.usgs.gov/open-file/of99-317/]. 